\title{
Magic Realism, Neurodiversity, and Carnivalesque in James McBride's Song Yet Sung
}

\author{
Yuan-Chin Chang \\ Department of Applied English Studies, China University of Technology, China
}

Received: 13-01-2016

doi:10.7575/aiac.ijclts.v.4n.2p.38
Accepted: 18-02-2016

Published: 01-04-2016

URL: http://dx.doi.org/10.7575/aiac.ijclts.v.4n.2p.38

\begin{abstract}
This paper considers James McBride's novel Song Yet Sung through multiple lenses - Bakhtin's Carnivalesque, magic realism and performativity as it relates to race and gender identities. It is considered how the character of the "Dreamer" can be read clinically as suffering the sequelae of a traumatic brain injury. Her symptoms, which include future hallucinations or prophecies, can be read as neurological symptoms of her multiple head injuries documented in the novel. Connected to this reading, the influence of magic realism is considered, particularly as it relates to the natural imagery and symbolism in the novel. The importance of birds, in particular, is considered. Carnivalesque as conceptualized by Bakhtin is also considered in the context of "magical" thinking and reading, and its connections to social subversion; this is considered in relation to the era of slavery, its legacy, and associated issues of gender and race.
\end{abstract}

Keywords: Carnivalesque, Magic Realism, Prophecy, Gender Performance, Racial Performativity, Identity Performance

\section{Introduction}

James McBride's novel Song Yet Sung (2009) is a rich, broad and darkly humorous work that considers the slavery era through the prophetic visions of Liz, an escaped slave. Irony and the fact that Liz's hallucinations represent contemporary times - inexplicable to her - make this a humorous book overall, despite its dark subject matter and narrative. In this aspect, Song Yet Sung - like McBride's earlier work The Good Lord Bird (2006)- can be read as a carnivalesque piece of literature employing grotesque realism and magical realism (Jefferson, 2001). Bakhtin's theory of Carnivalesque performance is resonant with the characters and narrative of Song Yet Sung, which does not shy away from depicting bodily grotesqueness and human cruelty or violence. However, as with Bakhtin's carnival, subversive behavior and poking fun at authority allow for a cathartic and empowering performance. Performance will be considered in terms of race and gender in relation to Song Yet Sung, following theories of Butler (1997) and others. Additionally, the connections between Bakhtin, Carnivalesque and magic realism in Song Yet Sung will be considered. Specifically, imagery and symbolism relating to birds, nature and the natural landscape will be considered in terms of the wider narrative regarding personal and societal freedom or slavery. Additionally, a brief neurological case study will be outlined regarding Liz and her special psychic powers and visions, which can be understood as natural sequelae resulting from two traumatic brain injuries the character suffers during Song Yet Sung. Liz's dreams and her dark visions of a future that nobody in her era can fathom serve to isolate and otherize her in the context of the novel's narrative. By extension, Liz's race and gender are also harshly otherized; as a black woman she is doubly oppressed (Hill, 2002). Resonances between the slavery era depicted and the current times can be established, and this is perhaps one reason that McBride's historically-grounded work serves to find resonance with modern readers. This paper will examine Song Yet Sung through these multiple lenses, considering the symbolism of birds, nature and the landscape in this novel and others, and the connections between animal-human relationships and symbols in literature with magical realism. Grotesque realism will also be considered in the context of Carnivalesque as outlined by Bakhtin in relation to medieval society; the carnival and circus-like elements of performance will then be paralleled with - and compared to performance issues in race and gender in history and in the present time. Through examining magic realism of the natural world in literature, Bakhtin's Carnivalesque, and the sequelae of traumatic brain injury, it can be seen that these three strands are connected by the theme of performativity. Identities, histories and realities can be understood as being performed to varying degrees - in their literary representations and in the real world alike. The overarching theme of performativity, and its relation to identity and history, can be traced through the representations of carnivalesque attitudes and actions, magical realism and specifically the connections between the natural world and the literary characters in Song Yet Sung. The prophetic visions of The Dreamer in the novel can be understood variously as the sequelae of a traumatic brain injury, and also as a facet of magic realism - this character foresees elements of literary or narrative reality that have not yet come to pass at the time of the narrative. Her performance is simultaneously that of a woman with brain function made atypical by trauma, and that of an individual with a higher state of consciousness and connection to the natural world - as an element of magic realism.

\section{Bird Symbolism}

Magic realism can be seen in McBride's work - as in the work of authors such as Gabriel Garcia Marquez - to involve 
fantastical animal life and natural elements. In McBride's Song Yet Sung, a particularly enduring symbolism in connection with magic is represented by the land and the weather, and also by birdlife as it is portrayed. The "song" and "singing" of the title can be read as relating to birds, as there are detailed and frequent references to different types of birdsong throughout Song Yet Sung. These descriptions are detailed and specific in describing bird species and their characteristics. For example: "A flock of blue warblers circled high over the Chesapeake, circling slowly towards Joya's Neck. Beneath them a tiny female figure holding a bucket stood and watched them circle lower with keen interest" (McBride, 2009, p. 101). These particular warblers are "coming north for spring" (101); in this aspect the movement of the free birds, and their song, is contrasted with the enslaved characters of the novel, who are commonly stuck on a particular farm or piece of land, only a matter of 'eighty miles' (101) from freedom in neighboring Pennsylvania. Therefore, the birds' free movement and migration becomes a mirror, and a sad contrasting element, to the difficulty with which enslaved or runaway characters cover physical and geographical distance.

The symbolism of, and attention paid to, bird life finds a parallel in James McBride's 2013 novel The Good Lord Bird. This darkly comedic piece of fiction tells of a slave who by chance travels with abolitionist John Brown over a period of years. In another parallel, the main character and narrator of The Good Lord Bird is mistaken for a girl despite being a self-identified male. In Song Yet Sung, the character of the Dreamer is portrayed as a beautiful woman, which gives a different perspective on the narrative from a feminine viewpoint. Portraying an era in which women's history was fragile and often told from a male viewpoint, McBride can be seen to be addressing this gendered imbalance in both Song Yet Sung and The Good Lord Bird. The Good Lord Bird represents a very interesting situation in which a selfidentified male passes in society as female, inhabiting a plural or fluid gender identity and performance in the wider realm. In both novels, birds are used as a symbol of freedom: in The Good Lord Bird, John Brown states to "Onion", the slave boy, that he has not kidnapped him but rather has freed him: "You just as free as the birds run" (McBride, 2013, p.27).

In The Good Lord Bird, the actual bird of the title is a recurrent symbolic theme. Onion is introduced to this "good Lord!" bird soon after he is taken away by John Brown, and the naming of the bird is done by Brown's son Frederick: "Up at the top of a thick birch, a woodpecker hammered away. He was a good-sized feller. Black and white, with a touch of red around him. 'Ever seen one of them?' he asked. 'I wouldn't know one bird from the next.' Fred stared up at it. 'They call that a Good Lord Bird,' he said. 'It's so pretty that when man sees it, he says 'Good Lord'." (McBride, 2013, p. 30). The black-white-red feather of this bird - a type of large woodpecker - is a visual emblem of the novel, and is ascribed with magical powers: "They say a feather from a Good Lord Bird'll bring you understanding that'll last your whole life." (McBride, 2013, p. 31). The multi-colored feather of the "good Lord" bird can be seen as giving understanding through symbolism; in the novel's narrative black and white people live in the same regions, homes and camps, yet there is sharp social and economic segregation according to racial divisions. Black and white therefore coexist in separate, stratified society and culture - as symbolized by the black and white feather of the bird. The red on the bird's black and white feather could be taken to stand for bloodshed and the violence of the era depicted in The Good Lord Bird, and also in Song Yet Sung; McBride does not shy away from portraying the cruelty and violence of the slavery era. In The Good Lord Bird, John Brown comes to represent the bird of the title, and he develops into a character seen by Onion as a man of great understanding, plurality, and as something of a savior. The bird is described circling overhead at the conclusion of The Good Lord Bird, just as birdlife is continually mentioned in Song Yet Sung as flying overhead. The implication is that birds - in addition to representing freedom - represent a kind of panoramic awareness or viewpoint that is achieved by certain characters in both novels. Alternatively it can be seen that the characters as a collective are able to outline a panoramic narrative and viewpoint, with a scope that is wider than any individual can see. In Song Yet Sung, The Dreamer's prophetic abilities are often connected to birds, nature and the web of living creatures. For example, The Dreamer plays guessing games while on the run in the wilderness:

She began to play guessing games in her head with the nature around her, saying to herself, I bet that little old bird there won't fly to the third branch on that tree yonder, and then watched with amusement as the bird flew exactly where she'd expected it to. She tried the guessing game several times, with a heron, a duck, with a redbellied turtle, and then an otter. There was something amiss about it - unsettling, to be certain - but it diverted her attention away from the real issue. (McBride 2008, 78-79)

Birds and the weather are also used as ominous symbols in Song Yet Sung. When trouble and violence approach in the narrative for the slaves and runaway characters, this is often foreshadowed through mention of a storm incoming. For example, in the section "hell in spite of redemption," it is stated: "A storm was coming, and Denwood sensed it would be a bad one. The mosquitoes rose out of the bog like clouds, and the ducks, wrens, and herons seemed thick as flies, all of them busy, scrambling for last-minute forage" (McBride 2009, p. 317). Birds and nature, throughout Song Yet Sung, are used to convey omens, foreshadowing, or elements of Liz's predictive visions. The birdlife, and nature generally, appear to predict the future, at least in terms of immediate weather. Liz's ability to predict the far future - eventually making a connection between her futuristic visions of the present time and a religious song from the slavery era - is intimately connected to the natural environment, and to the symbolism of birds particularly. As in The Good Lord Bird, the symbolism of birds is associated with understanding, plurality and an essential goodness. Liz embodies these elements in Song Yet Sung, as both Onion and John Brown represent them in The Good Lord Bird.

\section{Magic Realism and the Natural World}

Many authors using magic realism in their writing reference animal and bird life as essential elements. Schwalm (2009) indicates: 'Literary animals, in magical realism and elsewhere, are conventionally regarded as cyphers, symbols or 
props, whose importance lies in the meaning they give to others, the values they represent, or the role they play as part of the setting or landscape' (1). Symbolic animals - as represented in McBride's novels - are nonetheless connected to the real world; the natural environment is where Liz and other runaways sleep, eat and travel, especially those who are traveling northwards under cover of darkness. In Song Yet Sung, human use of animals such as dogs and horses is described from the very opening; notably, it is predominantly the white characters who have access to - and ownership of - such service animals. When Liz is shot and hiding in the water, a working dog tracks her. She drowns the dog for survival, in a clear parallel to the way she later, opportunistically yet essentially for her own survival, kills Little George. The symbolism of the dog is therefore transferred to the cruel rapist Little George; dog-like characteristics are highlighted in human counterparts. The relationships between human characters and animals or birds in Song Yet Sung are used to underscore relationships between different classes and races of human characters. Additionally, the animalor bird-like nature of individual characters is highlighted by their interactions with - or observations of - natural creatures. Schwalm (2009) states: 'magical realism typically blurs the boundaries between human and nonhuman animals, the exploration of what "animals" and "animality" mean is a concern throughout' (1). Literary theory generally has privileged discussion and criticism of human characters in literature; McBride's Song Yet Sung - in a magic realist and, later, Carnivalesque reading - uses birds and animals to underscore the reader's understanding of human characters. Therefore, to neglect the human-animal characters and relationships in this novel is to miss a significant depth in its magical elements. The symbolism of the animals is connected to the reader's existing knowledge to real-life animals and creatures; this provides the grounding for the imaginary natural landscapes and natural life portrayed in Song Yet Sung. The natural landscape of the area, moving from woods to bogs, waterways and the coast, is essentially a character in itself in Song Yet Sung, therefore, in terms of magical realism the natural landscape and its creatures should be considered not only as symbolic elements, but also essentially as literary characters in and of themselves. According to Schwalm (2009): 'Postcolonial magical realism embodies and represents an idea of feral animality that critically engages with an inherently imperialist and Cartesian humanism. It is through transcendence of the Cartesian subject that the embodiment and presence of animal agency can be acknowledged in the first instance, which, in turn, animates magical realism and injects it with life and vibrancy. Moreover, the postcolonial magical realist writers discussed in this dissertation use animal practices inextricably intertwined with imperialism, such as pastoral farming, natural historical collections, the circus, the rodeo, the Wild West show, and the zoo, as well as animal practices inherently incompatible with European ideologies, such as the Aboriginal Dreaming, Native North American animist beliefs, and subsistence hunting, as ways of engaging with, and positioning themselves in relation to the Cartesian human subject' (3-4). Further, Derrida (1974) indicates that white mythology is linked to the philosophical re-telling of history; clearly, this relates to the literary trajectory of magic realism in literature.

\section{Carnival and Bakhtin}

The tradition of magical realism involving animals has been closely linked to that of the circus (Schwalm 2006): "The Western circus tradition provides a particularly relevant framework for representations of animals in magic realist fiction, since magic realism and the circus are both closely related to Bakhtin's idea of the carnivalesque" (83). Although direct representations of the circus are not given in Song Yet Sung, the connection between Bakhtin's concept of "carnivalesque", circus traditions and magical realism means that circus should be considered in relation to McBride's work. Furthermore, there is of course a clear parallel in the way black people are treated by whites in Song Yet Sung, and the ways in which circus animals are treated by their captors. Slaves, in the era depicted by McBride, are kept captive, and expected to perform work for their owners' economic gain. Slaves' offspring are sold like animal livestock; white slave-owners such as Kathleen Sullivan in Song Yet Sung feel a protective fondness toward "their" slaves, without whom economic and physical survival would be difficult to impossible. The performance of not only manual labor, but also certain identities, is another parallel between the lot of circus animals and that of slaves.

Carnivalesque is a circus related theory developed by Russian philosopher Mikhail Bakhtin. His work, Rabelais and His World, is relevant to the present discussion of literary carnivalesque because it draws together concepts relating to carnival itself, and to dialogue. Bakhtin frames his work in terms of the social institution of carnival and the literary mode of grotesque realism. Carnival laughter and mockery of the ruling class were outlined in Bakhtin's world, and they can be understood as occurring in Song Yet Sung (Lindahl, 1996) Just as magical realism can be witnessed at work in Song Yet Sung, so too is grotesque realism. The reality of the slavery era - of violence, death and cruelty - is portrayed clearly in Song Yet Sung, though as with McBride's other works this is shot through with dark humor rather than a sense of unrelenting misery. The specific culture and performance practice of the post-slavery U.S. South has developed in response to the distinct forces shaping the history of that region (Hobson, 1999). The connections, tensions and relationships between carnival and grotesque realism form the core of Bakhtin's work. According to Bakhtin, the relationship between the person who is speaking and the one who is listening carries inherent meaning; this can be understood in the literary context of the relationship between writer, literary narrator, and reader. There is usually some kind of power relationship between these characters. Bakhtin defines an ambivalent kind of carnival, in a medieval historical context, simultaneously grotesque and subversive. When the state acts in an oppressive manner, the language of carnival can be used in a subversive or cathartic fashion - clearly, there is a parallel here with the totalitarian oppression and violence of slave-owning society, and the potential for slaves and former slaves to perform subversively. In the Middle Ages, a feudal society, carnival provided an outlet for subversive thought, opinion and behaviour. Bakhtin stated that "carnival celebrated temporary liberation from the prevailing truth and from the established order; it marked the suspension of all hierarchical rank, privileges, norms and prohibitions" (Bakhtin, 1984, p. 10). In Song Yet Sung, there is an "inside" and an "outside" world for the slave characters - they have learned to keep their emotional 
responses private and unseen by slave-owners, and they present a typically contained and obedient face to society. However, inside the social network of escaped and freed slaves, there is subversive and true expression of emotions and knowledge. The secret code discussed between the old woman and Liz at the outset of Song Yet Sung can be seen as a form of "inside" world as Bakhtin theorises as existing within the carnivalesque tradition. Within the carnival, according to Bakhtin, an alternative world of humour, folk knowledge and expression is created. This becomes a second layer or second world, in which carnival participants could express themselves relatively freely. The code outlined in Song Yet Sung, and the actual song which is revealed near the end of the novel, represents a folk tradition that enables expression and communication - for survival - between the slave characters.

Carnivalesque performance and culture is intimately tied to the grotesque, closely related to the human body and its functions. The carnivalesque elements of Song Yet Sung include grotesque depiction of violence, blood and gore, bodily functions, and the situation of characters within the earthy, realistic and often dirty natural world. This is contrasted with the artificial dissociation from natural, earthy and real life by those who seek to hold themselves within a higher socioeconomic class. Again, carnivalesque and grotesque realism can be considered as related to magical realism as it uses animals, birds and nature itself as not only symbols but real characters in relation to human characters. Medieval society as considered by Bakhtin was hierarchically structured, in terms of the church and according to the feudal system; therefore, carnival practice could interrogate the concept of, and the practice of, hierarchy (Jung, 1998; Holquist, 1990). The subversive nature of carnivalesque performance is often hidden in a playful mode of delivery; in McBride's novels, real horror and violence is often narrated with a humorous personal viewpoint or perspective, so that the writing itself can be seen as Carnivalesque in this aspect.

Huber (2009) states that the body "transgresses its own borders" (6); in daily performance in public, an individual's body constantly redefines its relationship to itself and to others. Bernstein (2011) indicates that such performativity begins in childhood, developing as an individual matures to adulthood. In Song Yet Sung, this can be seen in Liz's healing from being shot in the head, as the expulsion of the shot by her healing body is described in gruesome yet also somewhat magical language. Because of her dreams, Liz is known not only as "The Dreamer" but also as a "twoheaded girl" (McBride, 2009, p.18). In some ways, Liz does have two heads, or consciousnesses - one in the present and one in the future. She performs her dreams remotely as word of her visions spreads throughout the community of slaves, free slaves, runaway slaves and would-be runaways. Through Liz's visions, they are united without having met one another; this performance can be seen as a private one for the members of Liz's own community. The performances the black people in Song Yet Sung put on for white people are predominantly contained, circumspect and secretive; in a society where white people own black bodies, knowledge is power and not something to be given away. Huber, following Bakhtin, conceives of a carnivalesque, grotesque body as one which is open in terms of society; in Song Yet Sung it can be interpreted that Liz's brain and her visions are open among her own society, but contained and hidden from the majority of whites. The grotesque catalysts for Liz's psychic gift - being hit on the head with a flatiron as a child, then suffering a shot to the head - represent grotesque, carnivalesque bodily functions; yet, through the sequelae of these injuries she is able to become an "open" body spreading knowledge and community among her peers.

\section{Neurology and The Dreamer}

Considering Liz's prophetic dreams and visions specifically, this element of Song Yet Sung can be read as an interesting neurological case study, with links to magic realism and grotesque realism in the carnivalesque tradition. Liz is stated to have suffered at least two traumatic brain injuries in her life; her mystical visions and other symptoms such as suddenly losing consciousness or falling asleep unexpectedly can also be understood in terms of actual neurological response to TBI (Massagli et al., 2004). Vaishnavi et al. (2009) state: "Traumatic brain injury (TBI) is a significant public health concern... Neuropsychiatric problems are more prevalent and longer-lasting in TBI patients than in the general population. About $40 \%$ of TBI victims suffer from two or more psychiatric disorders... The entire spectrum of TBI severity, from mild to severe, is associated with an increase in psychiatric conditions" (198).

Jorge (2005) states: "Behavioral and psychiatric disturbances are the more frequent consequences of traumatic brain injury and major determinants of the quality of life of patients... The phenomenological characteristics and clinical correlates of major depression, post-traumatic stress disorder, alcohol use disorders, and post-traumatic brain injury attention deficit hyperactivity disorder have been studied in more detail" (289). Jorge (2005) also notes the increased prevalence of mood disorders among individuals who have suffered a traumatic brain injury. In the case of Liz, this can perhaps be implied by the fact that she does not wish to escape her situation or to flee to the north. Liz speaks, later in Song Yet Sung, of what sounds like major depression and despair: "I ain't afraid, she said. Death would be a relief to me, after what I been through. - What you been through? She wanted to tell him, tell him about the places she'd been and the people she'd seen, the terrible things she'd done to survive, the miles of emotional hardship she'd endured in her short life, but the years of molding herself into something she was not lay inside her like a block of granite, hard and unbreakable. So she said nothing" (McBride, 2009, p.158). Liz states: "There ain't no freedom up north. Not nowhere in this country. Ever. Everything that's taught here is a lie. Everything you and I got, has already done been taken. It's like that old woman said: every lie is a truth and every truth is a lie" (McBride, 2009, 158-9). Liz's dreams are prophetic visions that - if taken at face value - can be seen as TBI-related auras or partial seizures (Jorge, 2005). For example, her sudden nightmares are "filled with garish images of the future of the colored race - long lines of girls dressed as boys in farmers' clothing, young men standing before thousands delivering songs of rage that were neither sung nor played but rather preached over a metallic bang-bang that pounded out of tiny boxes" (McBride, 2009, p.5). Additionally, in terms of neurological study, Liz states that she is prone to sudden unconsciousness: "I got struck as a 
child and I fall asleep sometimes on no account" (McBride, 2009, p.10). Additionally, she experiences auditory hallucinations: "Liz heard a deep, baritone voice rumble. I been ready, the voice said. I been ready" (McBride, 2009, p.11). However, in the literary context, it can be seen that McBride is using Liz's symptoms primarily to foreshadow the narrative development of the novel, in which her dreams and visions bring unity and solidarity to others, ultimately through songs of faith. Also, the ironic humor of Liz's nightmares about the future of her race is written for the contemporary reader - the idea is that the reader will recognize, for example, hip-hop and rap culture as described by Liz, ostensibly from the viewpoint of the slavery era. Her visions lead Liz to despair for the future of her people, and for her own freedom from the trauma of the past.

\section{Performance of Race and Gender}

Eurocentrism in the time of slavery - and to the present day - led to the development of two issues which still affect American society to the present day - namely, "white racism and white supremacy" (Daniel, 2010, p.16). The unity and solidarity that spring up around Liz's status as "The Dreamer" and the "two-headed girl" can be seen as a spark of Afrocentrism. Daniel (2010) indicates that Afrocentrist thought "advance[s] the notion of a primordial African "race" and nation" (Daniel, 2010, p.217). The binary definition of race - as "white" and "colored", respectively - was essential to the functioning of the slavery trade and society of that era. The "one-drop rule" held that any person with "one drop" of black blood or heritage was considered to be non-white; against this demeaning and otherising definition of "white" and "colored", Afrocentric thought could foment "pride, solidarity and self-respect" (Daniel, 2010, p.217). Multiracial identities, performances and realities contrast with such a binary mode of racialized understanding and categorization (Dalmage, 2004; Hernandez, 1997). Considering race and gender alike, Butler's theories of performativity are relevant to the journeys and negotiations Liz and other characters make in Song Yet Sung. Butler(1997) views gender as a rehearsed performance; clearly, in Song Yet Sung, "colored" characters perform their race differently in relation to other black people, or to whites. The performance of deference, of dumbness and of being unemotional is part of racial performance for survival in the slavery era depicted by Liz and other characters in Song Yet Sung. Performance of racial or gender identity is fraught with difficulties in terms of external judgement if an individual is perceived to receive privilege through a particular performance (Brooks, 2006). In The Good Lord Bird, also, McBride touches upon this performance-for-survival element in a society sharply and binarily divided on color lines: "Truth is, lying come natural to all Negros during slave time, for no man or woman in bondage ever prospered stating their true thoughts to the boss. Much of colored life was an act, and the Negroes that sawed wood and said nothing lived the longest" (McBride, 2013, p.27).

The stratified and hierarchical construction of race, and gender, evident in Song Yet Sung was a product of the slavery era and slave trade. According to Daniel (2010) the concept of race as a system of distinct categories is relatively modern (p. 9). There was no hierarchical definition of race and racial categories until competing Western European nations in the New World sought to define whiteness as the default and "color" as the other. For these Europeans, Christianity was associated with whiteness: "Christian Europe viewed itself as morally superior to the darker-skinned infidels of the Afro-Eurasian world" (Daniel, 2010, p.14). Within non-white races and ethnic identities, lighter skin color and "white" racial performances often brought relative privilege to individuals or groups (Hollinger, 2003; Hunter, 2002). However, the Song Yet Sung in the novel is one of religious faith and unity; in this aspect, it can be seen that characters are reclaiming faith and faithfulness from white society, and determining by their own means whether they shall be considered "decent", good and "free" in the world. Religion functions as a unifier between black and white characters in some places in Song Yet Sung - for example, mistress Kathleen and her slaves share fondness for the Methodist church - yet faith and freedom are particularly intertwined for the black characters in the novel. The language and imagery of freedom is paralleled in that of religion - the underground railroad network through which escaped slaves reached the free North is referred to as the "gospel train"; the power of words and knowledge is understood and valued among a population that largely had their literacy restricted or neglected by slave owners.

In this context, racial performance is fraught, practiced and developed for survival. Liz, like other characters, has a panoramic understanding of the world - in Liz's case this includes present and far future. Black people understand and know whites in the context of slavery, employ behavioral subterfuge so that white people cannot reciprocally know and understand their interior lives to the same degree (Gross, 2001). Such behavioral performance is common to the enslaved people fearful of white wrath. The slavery era built such a survival-based behavioral template: "Back in them days white folks told niggers more than they told each other, for they knowed Negroes couldn't do nothing but say, 'Uhhuh,' and 'Ummmm,' and go on about their own troubled business. That made white folks subject to trickeration in my mind. Colored was always two steps ahead of white folks in that department, having thunk through every possibility of how to get along without being seen and making sure their lies match up with what white folks wanted. Your basic white man is a fool, is how I thought, and I held Fred in that number" (McBride, 2013, p.33). Slaves perform submissiveness, as do women in the historical era and - to a degree - in the current day. McBride's writing in Song Yet Sung is powerful because those negotiating their place in a racial hierarchy - and enduring patriarchy - will be familiar with such elements of performance, passing and behavioral subterfuge.

\section{Results}

Performativity connects literary magic realism, Bakhtin's Carnivalesque, and the sequelae of traumatic brain injury. Specifically in the context of the American South, personal and group performance affects, and is simultaneously shaped by, historical narratives and identities. All identities and historical tropes can be understood as being performed to at least some degree. Performativity connects the diverse elements discusses earlier - magical realism, 
representations of carnivalesque attitudes and the connections between the natural world and literary characters with a history of traumatic brain injury. The Dreamer's prophetic abilities can be explained as sequelae of a traumatic brain injury, or as part of a literary landscape based on magic realism and close attention to the natural and creaturely elements of human existence and society. The performativity of personal and group history - and how this relates to race and gender, among other facets of identity - is clearly outlined in Song Yet Sung. Specifically, magic realism and carnivalesque performance alike involve the use of exaggerated performances as a way of oppressed groups puncturing the cultural power of those with greater privilege. The Dreamer's brain injury is important in this element - obviously, it can be seen as a form of damage that disempowers her in life. However, the increased sensitivity and prophetic abilities that seem to have been brought about by the injury grant The Dreamer a specific power in her world, which is closely connected to both magic realism and Carnivalesque performance.

\section{Conclusion}

In Song Yet Sung, McBride uses a composite omniscient narrator through the use of multiple characters' perspectives. Additionally, Liz's futuristic dreams and visions provide a panoramic viewpoint on the narrative. These visions of a sad future for the black race can be taken as ironic humor, and also a connection between the slavery era and the present day. McBride's viewpoint and narrative is broad; it is universal, and in considering the performativity of race, class and gender it is anticipated that most readers will find a point of commonality with the portrayal of performativity in Song Yet Sung. Liz's dreams, visions, and other neurological symptoms can be interpreted, with the hindsight of the technological present, as perhaps a form of post-TBI syndrome, perhaps epilepsy. Temporal lobe epilepsy, in particular, is associated with prophetic visions, auras and partial seizures in which consciousness is altered and individuals may experience auditory or visual hallucinations. In Liz's case, the prophecies are for the benefit of the modern reader, and through their connection to historical and universal faith - they serve as a connecting point between Liz and other black characters in the novel, including those she does not actually meet. The power of words, of song and of shared experience runs throughout Song Yet Sung, and is reinforced as an emblem of freedom in the final revelation of the song and the singers.

Connections between the human and animal world are another important element of connections between song, freedom, expression and a magical or grotesque realism. The songs, movements and behaviors or many different types of bird are notated and discussed as background in almost every chapter of Song Yet Sung; the connections between the natural world and the weather, and the human drama of the novel are strong and magical. Liz is identified with birds and with wild creatures, and her prophetic sensitivity and strong faith are connected to the real, earthy, natural world. The human-animal relationships that underpin magical realism in the work of McBride and other authors are drawn with nuance and often also as an element of foreshadowing. Likewise, the weather is used - as in Thomas Hardy's novels as a character and a reflection or foreshadowing device of the dramatic narrative. People, animals and the natural environment are intimately intertwined in Song Yet Sung, with Liz's living in a burrow for much of the narrative more closely tying her to the animal world. In the natural world, however, lies great truth and realness, and through both grotesque realism and magical realism McBride outlines these truths via the characters' various quests for freedom.

Bakhtin's Carnivalesque, the sequelae of traumatic brain injury, and magic realism in connection to the natural world are all related clearly and inexorably to performance. All identities, histories and realities are performed in some way, both in the real world and in its literary reflection. Performativity, in relation to identity and history, can be traced through Song Yet Sung's representations of magical realism, carnivalesque attitudes and actions, and connections between the natural world and the literary characters in the context of a neurologically atypical character. The prophetic abilities of The Dreamer function as a certain identity performance, and also as a facet of magic realism Performativity of individual and group identity is a way of inverting power dynamics - even if temporarily - and therefore a way of reclaiming some personal freedom in a situation where the individual may be disempowered by societal norms and structures.

\section{References}

Bakhtin, M. (1984). Rabelais and his world. Trans. Helene Iswolsky. Bloomington, IN: Indiana University Press.

Bernstein, R. (2011). Racial innocence: Performing American childhood from slavery to civil rights. New York, NY: NYU Press.

Brooks, D. (2006). Bodies in dissent: Spectacular performances of race and freedom, 1850-1910. Durham, NC: Duke University Press.

Butler, J. (1997). Excitable speech: A politics of the performative. London, UK: Routledge.

Dalmage, H. M. (Ed.). (2004). The politics of multiracialism: Challenging racial thinking. Albany, NY: SUNY Press.

Daniel, G. R. (2010). Race and multiraciality in Brazil and the United States: converging paths? University Park, PA: Penn State Press.

Derrida, J. (1974). White mythology: Metaphor in the text of philosophy. New Literary History 6: 11-74

Gross, A. J. (2001). Beyond black and white: cultural approaches to race and slavery. Columbia Law Review 101(3), 640-690. doi: 10.2307/1123740.

Hernandez, T. K. (1997). Interests and rights of the interracial family in a multiracial racial classification. The Brandeis 
Journal of Family Law, 36(1), 29.

Hill, M.E. (2002). Skin color and the perception of attractiveness among African Americans: Does gender make a difference? Social Psychology Quarterly, 65(1), 77-91.

Hobson, F. (1999). But now I see: The White southern racial conversion narrative. Baton Rouge, LA: LSU Press.

Hollinger, D. A. (2003). Amalgamation and hypodescent: The question of ethnoracial mixture in the history of the United States. The American Historical Review, 108(5), 1363-1390.

Holquist, M. (1990). Dialogism: Bakhtin and his world. New York, NY: Routledge.

Huber, M. (2009). (Re-)Covering queer: Restarting public space and sexual politics. In José Belbel. M and Reitsamer, R. (Eds.), dig me out: Discourses of popular music, gender and ethnicity (pp.1-18). Art Centre Arteleku, Spain/Austria.

Hunter, M.L. (2002). "If you're light you're alright": light skin color as social capital for women of color. Gender and Society, 16(2), April, 175-193.

Jefferson, A. (2001) Bodymatters: Self and other in Bakhtin, Sartre and Barthes. In: Hirschkop, Ken and Shepherd, D. (Eds.) (2001): Bakhtin and cultural theory,( $2^{\text {nd }}$ ed., pp. 201-118). Manchester, UK: Manchester University Press.

Jorge, Ricardo E. (2005). Neuropsychiatric consequences of traumatic brain injury: a review of recent findings. Current Opinion in Psychiatry 18(3), 289-299.

Jung, H. Y. (1998). Bakhtin's dialogical body politics. In M. M. Bell \& M. Gardiner (Eds.), Bakhtin and the human sciences (pp. 95-111). London, UK: Sage..

Lindahl, C. (1996) Bakhtin's carnival laughter and the Cajun country Mardi Gras. Folklore, 107(2): 57-70.

Massagli. TL, Fann. JR, Burington. BE, Jaffe. KM, Katon. WJ, and Thompson. RS. (2004). Psychiatric illness after mild traumatic brain injury in children. Archives of Physical Medicine and Rehabilitations, 85, 1428-1434.

McBride, J. (2009). Song yet sung. London, UK: Penguin.

McBride, J. (2013). The good lord bird. London, UK: Penguin.

Schwalm, T. (2006). "Relax and enjoy the show": Circensian animal apaces in Australian and Latin American magical realist fiction." The Journal of Commonwealth Literature 41(3): 83-102.

Schwalm, T. (2009). Animal writing: magical realism and the posthuman other. (Doctoral thesis, University of Canterbury, Auckland, New Zealand). Retrieved from

http:// http://ir.canterbury.ac.nz/bitstream/handle/10092/4470/thesis_fulltext.pdf?sequence=1\&isAllowed=y

Vaishnavi. S, Rao. V, and Fann. J. R. (2009). Neuropsychiatric problems after traumatic brain injury: unraveling the silent epidemic. Psychosomatics 50(3): 198-205. 